\title{
Public Sector Corruption In Nigeria
}

\author{
Greene I. Eleagu
}

\begin{abstract}
Corruption is a monster that has held Nigeria hostage for a long time. Public institutions created to effect public good or collective welfare have been turned into personal fiefdoms by the privileged few. Indeed, according to saharareporters.com (Olorunfemi,2016) there is currently an attempt by the senate to decriminalize corruption by seeking to amend the CCT Act "while the senate president is standing trial for a breach of the (same)law". As at now the bill has passed its second reading and only awaits a third at the national assembly to become law. This paper therefore is an attempt to highlight the causes, patterns and consequences of corruption in Nigeria.
\end{abstract}

\section{INTRODUCTION}

Many global organizations and the World Bank define corruption as the abuse of public office for private gain. Transparency International defined it as "the abuse of entrusted power for private gain. It can be classified as grand, petty and political, depending on the amounts of money lost and the sector where it occurs"(transparency.org). It is said to involve the seeking or exacting of a promise or a receipt of a gift or any other advantage by a public servant in consideration for the performance or omission of an act, in violation of duties required of the office. Corruption is the abuse or misuse of power or position of trust for personal or group benefit (monetary or otherwise).

Asobie (2006:4,5) queried this definition as being public sector-centered. Therefore, he asserts that corruption "describes a pattern of behavior that can be found in virtually every sphere of life". Corruption is a social and economic problem. According to the ICPC Act (section 2), corruption includes vices like bribery, fraud, and other related offences. Corruption is a global phenomenon and became so prominent that UN in 2003 set aside December 09 of every year as World Anti-corruption Day to create awareness on the dangers corruption poses to societies. It involves dishonest or fraudulent conduct by those in power, typically through bribery. It is found in local, regional and international bodies. In spite of benefitting to varying degrees from globalization, many countries like Nigeria, Turkey, Egypt, Ukraine, India and Brazil have all failed to evolve politically to meet the expectations of their people largely due to high levels of corruption in government and business. According to Nwaze (2012) “...it is trite to state that corruption is no respecter of continents, regions or other ethnic groups. It abounds everywhere". Although corruption is global in spread Mungiu-Pippidi (2015) has argued that it is a weapon of impoverishment of the weaker nations by the stronger.

The economic crisis exposed the hypocrisy of rich countries which control corruption at home but use it to advance their economic interests abroad. The rise in the last two decades of an international anticorruption regime only raised awareness but failed so far to diminish corruption.

According to the Daily Sun (June 12,2015, p16), China's former security chief, Zhou Yongkang, was "sentenced yesterday to life in jail for bribery, leaking state secrets and abuse of power". Several officials of the world soccer governing body, FIFA, have at one time or the other been indicted or punished over corruption and match-fixing scandals. On June 12,2015, a former Indian leader was indicted for corruption. In the USA former NY Senate Leader, Skelos and his son, Adam Skelos "engaged in a corrupt scheme to monetize the elder Skelo's position as head of the Senate" (Dewitt,2015). What makes the Nigerian and African cases different is the impunity involved. Officials are hardly prosecuted and where they are, they either bribe their way out or frustrate prosecution until public interest is shifted from such cases. According to an editorial in the Daily Sun of June 08, 2015 a convicted drug trafficker who had been tried and given a jail term for drug trafficking was recently arrested with hard drugs at the Kano airport, obviously without serving the earlier sentence. According to the Daily Sun of February 03, 2016 “... at least 12 Nigerians were named in the US court records as having received various sums of money as bribes". The paper went on to observe that "at least 14 Nigerians were named in German court records to have received various sums as bribes from Siemens". Curiously, none of these people "has been questioned or made to account for their misdeeds till date".

The paper stated that the case of

Halliburton arose from huge contracts awarded by the Nigeria Liquified Natural Gas,NLNG, between 1995 and 2004. A consortium of four international Companies won the $\$ 6$ billion deal. But, in the course of investigation into the activities of ELF in France, one of the officials revealed that the consortium won 
the contracts by bribing key government officials and politicians in Nigeria. It went further to state that in court proceedings in Houston, KBR, the Halliburton subsidiary member of the consortium, pleaded guilty to conspiring with its joint venture partners and others to pay bribes amounting to about $\$ 180$ million to a range of Nigerian government officials, as well as a political party to obtain the contracts (Daily Sun of February 03, 2016). As was the routine and perhaps to make it look clean a high-powered panel headed by the InspectorGeneral of Police was, at a time, constituted to investigate the matter and the membership included the chairman of the Economic and Financial Crimes Commission (EFCC), a representative of the National Security Adviser (NSA), a representative of the Director-General of the State Security Service (SSS) and a representative of the Director-General of the National Intelligence Agency (NIA). "With such a panel, Nigerians had expected a thorough investigation and an accurate report. But, nothing came out of that effort as the report on the investigation never saw the light of day" (Daily Sun of February 03, 2016). $\quad$ Nkpoyen et al (2014:104 - 112) argue that Nigeria, as a country, is blessed with abundant human and natural resources which if properly harnessed would have turned this country into a developed economy. But given the massive corruption, lack of commitment, the dominant role of the public sector in the economic life of the nation, the country has lost opportunities for growth and sustainable development. Corruption has become a common phenomenon in many developing economies.

\section{METHODOLOGY/THEORETICAL FRAMEWORK}

The methodology is chronological, based on situational analysis. The elite theory will guide the study. According to Ezeani "The origins of this theory can be traced back to the writings of particularly Pareto (1939), Mosca (1939), Michels (1949) and Ortega(1932)" . According to Pareto (1939) "every society is ruled by a minority that posseses the qualities for its accession to full social and political power" (Ezeani,2010:96). Pareto opined that the elites rule with a combination of force and cunning. It is possible thus to argue that it is within this ruling elite that corruption that has to do with political power is domiciled.

Mosca (1939) further developed this theory, pointing out that, in oligarchy, being the only form of government, as opposed to Aristotle's monarchy, aristocracy and democracy, there are two classes of people. These include, he said, the minority ruling class and the massive ruled class. Mosca said that the elite or ruling class succeed in ruling over the masses because they are organized and posses intelligence and "have aptitude for mathematics, musical talent, moral character, et cetera"(Ezeani 2010:97). Both Pareto and Mosca agreed on circulation of elites. For Pareto the degeneration of and consequent circulation of the elites are due to changes taking place in the psychological characteristics of the different categories of elites.

In Nigeria, for instance, there was an influx of local but internationally acclaimed fraudsters into governance following the restoration of democracy by the military government of General Abdulsalam Abubakar in 1999. Prior to this time several efforts by well-meaning elite to go into government were frustrated by the insincere military governments. Indeed, Chief M.K.O.Abiola, that was widely acclaimed to have won the free and fair elections of 1993 was detained and he died in suspicious circumstances in prison in 1993 after the election was annulled by General Ibrahim Babangida. Thus in 1999 a new set of, albeit corrupt, political elites ascended political leadership in Nigeria, being the only people with enough courage and cash to take the chance.

This elite theory can be expanded to operate also at the international levels also. And so, MungiuPippidi (2015) argued that corruption is a weapon of impoverishment of the weaker nations employed by the stronger nations. The usually few in number hypocritical rich countries control corruption at home but use it to advance their economic interests abroad. In spite of the awareness raised in the last two decades of an international anticorruption regime corruption levels refused to diminish. Whether at the international or local level the number of nations or people (elite) cheating the others is always small. According to Naija.com December 01,2015, at the opening ceremony of the First International Conference of the African Studies Association of Africa held on Wednesday, October 14,2015 in Ibadan, Oyo state Obasanjo agreed that regimes in Africa were often corrupt but often due to external influence. "We got loans, some dubious, others used to acquire weapons and we ended up in debt and instability that gave us only more pains, coups and counter-coups and bad governance. Some of the worst dictators in the world emerged from Africa with the full endorsement and encouragement of outside influence". PM News reports that Obasanjo expressed his concern speaking on "African Studies in the Twenty-First Century: Past, Present and Future."

Speaking at the event that was hosted by the Institute of African Studies, University of Ibadan, Obasanjo stressed that one of the main challenges for the African continent was corruption, and urged African nations to rise up and defeat it.

\section{INCIDENCE OF CORRUPTION IN NIGERIA}

Nigeria was colonized by Britain in 1885 and became a British protectorate in 1901 (informationng.com/2015). She became independent in 1960 and a republic in 1963 . The coexistence of vast 
wealth in natural resources and extreme personal poverty in developing countries like Nigeria is referred to by economists as "resource curse" which fuels official corruption.

Many successful coup plotters and subsequently rulers of Nigeria often hinged their entrance into governance on the intolerable levels of corruption in the country. However, each successor regime, civilian or military, appears to have almost always indicted its predecessor over the same matter of corruption. In 1999 when President Olusegun Obasanjo came to power he zeroed in on the oil sector, a popular first port of call for every new regime in the usual lip service about fighting corruption. Addressing a delegation of Isoko Development Union in 2003 Obasanjo had been quoted as saying "I, on my honour will ensure that the anticorruption war is won. I will do all that is humanly possible to make sure that we do not fail" (Daily Sun, August 31,2015:09). However, instead of abetting his regime only succeeded in glossing over corruption and indeed bequeathed a myriad of gargantuan cases of bribery and corruption, like the oil bloc bazaar (This Day Newspaper, May 13,2009), the Halliburton, NITEL and LNG cases which were said to involve high profile national and international governments, to the successor regime.

According to naijaparrot.com recent reports President Olusegun Obasanjo and the then FCT minister, Mallam Nasir El-Rufai, were accused by the project manager, Etim Abak, of a Chinese firm of awarding the Abuja rail project in 2007 without an engineering design or a Memorandum of Understanding. Abak was said to have told the Senate Committee on the Federal Capital Territory that:

"The Minister of FCT and current governor of Kaduna State, Mallam Nasir el-Rufai, allegedly signed the $\$ 841.645,898 \mathrm{~m}$ contract based on an uncalculated estimate... He told the committee that the contract, which was for 60.67 -kilometre rail project, was inflated by $\$ 10 \mathrm{~m}$ per $\mathrm{km}$ and that the length was later reduced to $45 \mathrm{~km}$ without refund of the cost for the $15.67 \mathrm{~km}$ that was dropped off from the project."'

Many thought that the military regimes of 1984 to 1999 were simply corrupt. It was a thus a huge relief to many when democracy was restored in May 1999. However, events of Halliburton, LNG etc soon proved everybody wrong. Indeed Doris Obinna (Daily Sun, August 03,2015:05) quoted second Republic minister of justice and attorney-general of the federation, Chief Richard Akinjide(SAN), as saying that states were unable to pay salaries because their governors "are stealing. The biggest thieves are the governors". Some of the governors receive as high as N750 million monthly security vote in areas that have little or no security challenges, as against N18,000 minimum wage. This security vote is constitutionally shielded that the governors are not required to account for how they spend the money.

According to Akinjide (Obinna,2015:05), the critical things in life are honesty and integrity which when lacking in government result in corruption and then to poverty in the land.

For instance, soon after General Sani Abacha regime took over political power in Nigeria in 1994 it initiated the Petroleum Trust Fund, PTF as a tool to alleviate poverty in Nigeria through construction of roads, building of schools and hospitals, provision of drugs in hospitals, among others. However, it was not long before the body was accused of lopsidedness, regional favouritism and outright corruption. Maduagwu(2011:16) observed that: Had Buhari been honest in his management of the Petroleum Trust Fund, PTF, the amount of money that was in his disposal, he would have alleviated Nigerian poverty tenfold. Obasanjo has earmarked N10 billion to fight poverty, but according to a newsmagazine report ( Newswatch), Buhari had an average of N52 billion every year to spend on Nigeria. At the end of the PTF reign Nigerian poverty and underdevelopment level remained the same, if not worse, as prior to the establishment of the PTF. Nigerians were fooled by the two former Head of States, Buhari and Abacha. Dr Haroum Adamu's interim report says that N135 billion out of the N146 billion was squandered, possibly through over invoicing, over supplies, supplying expired materials, wrong project priorities, settling perceived trouble spots, like the army and the police, and blatant thievery.

The sheer weight in 1999 of allegations of mismanagement and corruption against the PTF led the Obasanjo administration set up an Interim Management Committee to investigate the PTF. The Committee found that the PTF had income in excess of N181 billion from mid-1994 to July 1999. Karlmax2 (2014) wrote extensively on how Buhari managed the PTF: The management structure of the Fund was so capricious, from start, as in retrospect to suggest that the executive chairman was far more impressed by his position as an alternate Head of State, an Interventionist Czar who was answerable to no one, not even the Head of State himself, than anything else. First, he unilaterally appointed a single consultant, Afri-Projects Consortium, as the sole adviser to the Fund. Then he delegated virtually all his powers to this agency. Afri-Projects Consortium was given the exclusive power to initiate projects, assess their probable cost, approve the costs, execute the projects, and assess the quality of execution, all alone. The Consortium's decisions could not be questioned by anyone outside the Fund. Even the statutory members of the Fund's Board of Trustees found themselves helplessly watching as huge sums of money were paid out for questionable projects. And not surprisingly, the three professional management firms recruited by the Interim Management Committee to audit the performance of Afri-Projects Consortium came up with the unanimous conclusion that APC had over-charged the Fund for its services to the tune of over $\mathrm{N} 2$ billion. 
According to Karlmax2 (2014) the findings revealed that the APC which directly managed the HIV/AIDS Intervention Programme of the Fund knowingly imported sub-standard, poorly packaged, poorly stored, expired, or soon to expire treatment kits and drugs. It cost the government N579 million by stocking huge silos of useless drugs and kits, purchased at inflated prices. The findings further revealed that the health sector was also not spared as the PTF purchased large quantities of spectacle frames which were at the time costing only N800 a piece locally, for N1,900 a piece. This cost the public treasury over N45 million in inflated charges. The IMC's consultants made other shocking revelations. Ambulances whose going price at the time was N3 million each were found to have been purchased for N13 million each, leading to a loss to the treasury of N900 million. PTF, through APC, purchased general drugs at the cost of N3 billion. The Interim Management Committee's consultants concluded that the Fund had been cheated by as much as N1.5 billion through inflated charges, and because most of the drugs had already expired before they could be safely used. The Interim Committee's consultants also discovered that PTF had decided, without approval from the government, to build a residential estate in Wuse, Abuja, a project which was clearly outside the scope of its intervention mandate. The project purportedly cost PTF N703 million. But the consultants concluded that a realistic valuation of the project could not exceed N328 million. The project cost was inflated by more than 100 per cent, at N375 million. Continuing the report notes that in virtually every other area of PTF activity, three separate consultants engaged by the Interim Committee, and working independently, concluded that there had been massive fraud or criminal mismanagement of funds belonging to Buhari's empire. The Headquarters Extension and Renovation Project of the PTF cost the Fund N461 million. The consultants determined that it should not have cost more than N326 million. The Fund had been defrauded by N135 million.

The PTF had three main bank accounts. The independent consultants concluded that the Fund had been short-changed by as much as N3.6 billion by way of short payment of interest accruals from deposits, or excessive charges on Cost of Turnover by preferred banks. The Rural Water Supply Scheme was another funnel from which huge sums of money were siphoned away. The independent consultants determined that as much as N1 billion was recoverable from inflated costs and mobilisations for work that was never done. They discovered, also, that the Fund had lost as much as N900 million in the Educational Materials Supply Scheme, through inflated charges and non-performance of contracts duly paid for. The Rural Telecommunications Development Scheme was another such scheme from which money was cynically carted away by favoured clients.

The scheme was designed in two parts: a Pilot Phase, and the Main Phase. The Pilot programme was intended to determine the viability of the project. But this did not deter PTF, under Gen. Buhari, to award contracts for the main programme to the tune of N1.6 billion, without any contracts signed, and before any conclusions could be drawn from the Pilot project. It is a horrendous story of criminal negligence, cynical fraud, and unprecedented disregard for all civilised standards of prudence and transparency in the disbursement of public funds. In the end, the independent consultants concluded that of the N181 billion that accrued to PTF in the four and a half years of its existence between July 1994 and July 1999, as much as N25 billion was either stolen or improperly expended (Karlmax2, 2014).

The PTF was also accused of clannishness and regional favouritism. Quoting figures from PTF Situation Reports (Vol. 2 Dec. 98) the Afenifere (nairaland.com) claimed that the PTF carried on as if there was no South West. The report went on to claim that:Of all the roads rehabilitated by the PTF, only 1984.5 kilometres of roads representing 10.84 per cent were carried out in the South West; from where the bulk of the PTF revenue came since the zone consumes over 60 per cent of refined petroleum products. All the Southern States had 4,440.43 kms or 24 per cent of road rehabilitation as against $13,870.47 \mathrm{kms}$ or 76 per cent in the Northern States zone three comprising the North-West States of Jigawa, Kaduna, Kano, Katsina, Kebbi, Sokoto and Zamfara had a lion share of $5020 \mathrm{kms}$ or 27.42 per cent because the Fund's Chairman, Buhari and the military dictator Sani Abacha were from there; zone four comprising the North-East States of Adamawa, Bauchi, Borno, Gombe, Taraba and Yobe picked 23.48 per cent. This is the zone where Salihijo Ahmed, the late Chief Executive of Afri-Project Consortium APC, the sole consultants that supervised all PTF projects came from. Figures in other sectors were more scandalous. For instance, under the National Health and Educational Rehabilitation Programme (NHERP), the South West had zero allocation in the tertiary programme, while the North picked 100 per cent. In the vocational programme, the South West had zero while the North had 97 per cent. In the primary area, the South-West had zero against 88 per cent for the North and in the secondary area, it was zero for the South-West and 86 per cent for the North. The health sector is similar. For the Teaching Hospitals, the South-West had zero while the North had 62 per cent. For the Specialist Hospitals, it was zero for the South-West and 71 per cent for the North; in General/State Hospitals the Yoruba had nothing while the North had 56 per cent for health clinics, it was zero for the South-West against the North's 100 per cent (Afenifere nairaland.com). 
Under the food supply summary, the Southwest had 7.26 per cent compared with 83 per cent for the North, Buhari's zone having 60.54 per cent to itself. The Northern wielders of power have skewed all demographic indicators to marginalise the Yoruba and confer undue advantage on the North. For instance, while the old Kano and Lagos used to have the same number of divisions, various demographic manipulations over the years have brought about absurd disparities between the two states. While the old Lagos remains a state with 20 local governments, the old Kano has become two states-Kano and Jigawa with 77 local governments. These are some of the indices used for revenue sharing (Afenifere nairaland.com). The late President Umar Yar'adua succeeded Obasanjo and on May 12,2009. He pointed accusing fingers at a cartel in the oil sector (This Day Newspaper, May 13,2009). His regime discovered oil block bazaar that took place under the Obasanjo regime. According to UNODC unscrupulous leaders pilfered the national coffers and stashed away billions of dollars in foreign bank accounts.

By some estimates close to US \$400 billion was stolen between 1960 and 1999. Sani Abacha alone is estimated to have stolen the equivalent of 2 - 3 per cent of the country's GDP for every year that he was President. That is a staggering - almost "astronomical" - amount of money because if you were to put 400 billion dollar bills end-to-end, you could make 75 round trips to the moon! Concretely, those 400 billion dollars could have translated into millions of vaccinations for children; thousands of kilometres of roads; hundreds of schools, hospitals and water treatment facilities that never came to be. (unodc.org/unodc/en/frontpage/nigerias-corruption-busters.html).A commentator (Okey Ndibe,2015) observed that a " cursory look at Nigeria suffices to conclude that here's a land run by contemptible thieves with puny minds. There's a clear inverse relation-ship between the country's considerable earnings and its depth of destitution, infrastructural back-wardness and environmental blight". Ndibe went on to observe that

In late September 2006, Nuhu Ribadu, the pioneer chairman of the Economic and Financial Crimes Commission (EFCC), told Nigerian senators that the agency had dossiers, implicating numerous top political officials in 31 out of Nigeria's 36 states...... Nine years after Mr. Ribadu's address to a plenary session of the Senate, the EFCC's record of prosecution and conviction of prominent political figures remains, simply, dismal. It's as if the thieves manage, somehow, to be invisible. No former Nigerian military dictator or their uniformed cohorts ever fiddled with a kobo of public funds. Never mind that they live in obscene splendour, often boast a private jet or two, and sit, it seems, on a bottomless pile of cash. We're supposed to allow that it's all the fruit of their extraordinary industry and preternatural intelligence.

A popular salutation in the police force in Nigeria is All Correct, sir. This usually comes from the junior to the senior to indicate that his dressing, combat readiness, etc are all correct. However, it has largely been turned or corrupted into a joke among the force members to sound All Corrupt, sir. This signals that the person saluting, the person being saluted and all others around are corrupt. And usually it is laughed off. Current statistics reveal that Nigeria has one policeman to 2,000 persons to protect, instead of the United Nations recommended one to 450 citizens (un.org). In spite of this ugly position many of the available police personnel are often illegally deployed by the divisional police officers to guard VIPs. It is a common sight to see armed police men escorting wives of VIPs even to markets to buy foodstuff. The same officers who are paid with public funds turn blind eyes to security challenges that arise on their way to such market places. Even when they encounter traffic gridlocks they simply alight from their air-conditioned SUVs, clear the road enough to let their convoys get by and then zoom off, leaving everybody else to "find his way".

The prison system is equally compromised. Reports indicate that reformation that would have benefitted inmates or convicts is sometimes aborted as they never get to serve such sentences if they can pay enough bribes to the prison officials. In one particular incident a convicted drug peddler who was supposed to be serving jail term ran foul of the same law and was apprehended at the Kano airport. Naturally, this raised a red flag and subsequent enquiries by NDLEA(anti-drug agency) revealed that many drug traffickers who had been given jail terms by the courts had been surreptitiously let out of prison illegally (Daily Sun,08/06/2015).

Until the Power Holding Company of Nigeria, PHCN (formerly National Electric Power Authority, NEPA) was sold to private hands recently consumers were often fraudulently kept in darkness long enough for them to contribute money to buy or replace weak or stolen transformers. Such contribution of resources suffered various degrees of fraud or compromise at various levels. Of course the bills kept coming to the consumers regardless of whether power was supplied or not. Some people (Ayobami, 2011) even believe that transformers were being vandalized by NEPA officials to warrant either replacement or repair of the transformers. Of course,such replacements or repairs meant extra undeserved cash for the then NEPA staff .

\section{EFFECTS OF CORRUPTION}

Corruption according to Transparency International (2015) corrodes the fabric of society and undermines people's trust in political and economic systems, institutions and leaders . Some of the effects or costs of corruption include misallocation and misappropriation of resources, inadequate infrastructure, failures in government performance, rise of angry middle class and weak anti-corruption agencies/institutions 


\section{MISALLOCATION AND MISAPPROPRIATION OF RESOURCES}

Corruption, according to Nkpoyen (2014) drastically affects economic development by causing a misallocation and misappropriation of resources (human, material and informational). What is damaging to an economy is the fact that in endemically corrupt systems, a larger segment of the population does not get served by the government and as they do not trust the government they do not interact with the government. As these people have to get things done, they create their own systems to do things and in the process carry out unethical actions detrimental to development. In a country of over 160 million people only 109 senators and 360 House of Representatives collect about N150 billion annually. Due to public outcry over this rape on the economy the eight senate decided to cut only N30 billion from its annual allowances. The Nigerian Labour Congress recently queried the token slash from N150 billion to N120 billion by the eight senate (Daily Sun,Wednesday,June 22,2015,p3). According to analysis of the NLC the N120 billion in a year for national legislators is twice the Ekiti state 2015 budget of $\mathrm{N} 80.774$ billion, a state with a population of 2,384,212 people. Osun state has a population of 3,423,535 people, an unfunded Appropriation Bill N201 billion and is yet to pay salaries for seven months. Benue state budgeted N98.54 billion for as many as 4,219,244 people; Zamfara has 3,259,846 citizens and budgeted N92.80 billion; and Ebonyi budgeted N80.02 billion for 2,173,501 people . The implication is that the sum of these three states' budgets is just half of that of the National Assembly. Again, even Kano state with a population of 9,383,682 has a budget of N210 billion. This converts to budget per capital of N22,379 as against budget per capital of N293,398,533 for the same year.

Another display of misallocation of resources can be found in the unfortunate report (Daily Sun,Wednesday,June 24,2015,p17) that amidst claims by the current governor of Bauchi state, Mohammed Abubakar, that his predecessor Mallam Isa Yuguda left an empty treasury and a debt of N125 billion "22 Sports Utility Vehicles (SUVs) belonging to the state were seized from three of the former governor's wives".

\section{INADEQUATE INFRASTRUCTURE}

Ihejiamaizu (2001) traced the cause of inadequate infrastructure in our society to corruption, while Aderinwale (2005) blamed corrupt practices for the implementation of badly designedprojects with no economic or commercial viability. Cost escalation has resulted in pricing policies which have kept the services beyond the reach of ordinary masses who are expected to be the beneficiaries. In some cases, projects have been abandoned, both complete and uncompleted after substantial public funds have been expended (Nkpoyen, 2014).

\section{FAILURES IN GOVERNMENT PERFORMANCE}

Corruption (Mungiu-Pippidi, 2016) has become the main explanation for failures in government performance, for webs of nepotistic interests, and for billions of euros in disappearing public funds, national or assistance funds. India has had the most explicit response, with the emergence of a successful anti-corruption political party, and the viral, cross border success of the website, ipaidabribe.com. But all recent urban protests place corruption near the top of their list of grievances - from the Occupy movement to the Arab Spring.

In Nigeria corruption has largely been responsible for her consistent ranking by the World Bank and the UNDP on the Human Development Index, HDI. The UNDP has classified the country as 141 poorest nations on human development index. In its report, Nigeria is considered one of the 20 poorest countries in the world with $70 \%$ of the population classified as poor and $54.4 \%$ living in absolute poverty (UNDP-HDI, 2006). Recent studies have revealed that the various campaigns against poverty are yet to record any meaningful success. The UNDP report (2010) covering a period of 2000-2008 indicates that $64.4 \%$ of Nigerians live below poverty line, while the country occupies $142^{\text {nd }}$ position out of 147 countries in human development index.

\section{RISE OF ANGRY MIDDLE CLASS}

Mungiu-Pippidi ( 2016 ) observed that from Turkey to Egypt, Bulgaria to Ukraine, and Brazil to India, we witness the rise of an urban angry middle class protesting against what they see as fundamental corruption of their political regimes, perceived as predatory and inefficient.

\section{WEAK ANTI-CORRUPTION AGENCIES/INSTITUTIONS}

The drafters of the 1999 constitution of Nigeria recognized the enormous presence of corruption in Nigeria and sought to address it in section 15(5). That section provides that "Government must eradicate all forms of corrupt practices and abuse of power". The Independent Corrupt Practices Commission (ICPC), (in full the Independent Corrupt Practices and Other Related Offences Commission) is a Nigerian agency that was inaugurated via the Independent Corrupt Practices and Other Related Offences Commission Act 2000 on September 29, 2000 by the President Olusegun Obasanjo administration. The mandate is to receive and 
investigate reports of corruption and in appropriate cases prosecute the offender[s], to examine, review and enforce the correction of corruption prone systems and procedures of public bodies, with a view to eliminating corruption in public life, and to educate and enlighten the public on and against corruption and related offences with a view to enlisting and fostering public support for the fight against corruption.(Wikipedia).

Institutions charged with oversight functions including NASS, EFCC, ICPC are themselves battling with image problems. For the eight years Obasanjo was in office as president, the anti-crime agency, EFCC, was largely seen as a toothless bulldog, often available as tools to victimize opposition. Its notoriety was heightened by its inability to secure judgements over its many suspects. The Commission was known for preferring as many as a thousand cases against a single suspect. Curiously, however, it scarcely could convince judges over any of the judges. What highlighted the weakness of the agency was the ex-Ggovernor James Ibori money laundering saga. The agency had dragged Ibori to court over numerous charges bothering on money laundering but could not prove any of them in the courts. Ibori was announced a free, blameless man and his acolytes found occasion for celebration. It took just one charge with diligent prosecution by the British government to nail the same Ibori over the same money laundering problem in 2012. Indeed, he admitted to committing the crime and was duly sent to prison in Britain.

As Obijiofor (2015:51)observed "The cataclysmic failure of the EFFC to seize, prosecute, and secure guilty verdicts against fraudulent high profile politicians and public officials has reinforced many people's perception of the anti-corruption agency as deeply troubled organization that has no clear strategies or map with which to tackle the challenges posed by corruption to national socioeconomic development. That is the tragedy that engulfed the EFCC. An agency of government that has no idea about the direction in which it is headed is like a ship without a captain drifting and floating in the ocean" Another prominent challenge is the snail pace of adjudication in the country. Some cases can crawl for years at various levels of the courts until public interest is lost and then lack of diligence in prosecution can be exploited by the defence lawyers. This is in addition to deliberate attempts to befuddle the outcome through motions for adjournments and injunctions by the defence lawyers. In Nigeria's legal system, some people are above the law; they are untouchable and cannot be prosecuted. Consider this. When the House of Representatives set up an ad hoc committee to probe how the oil subsidy revenue was used or embezzled by several business corporations, what emerged was an astounding corruption scandal involving Farouk Lawan, chairperson of the House panel investigating the fuel subsidy fraud, and oil magnate Femi Otedola, who was accused of offering $\$ 620,000$ bribe to Lawan so he could influence the panel's report and prevent any indictments against Otedola. Although the case is still in the court, the EFCC did not show interest in the case in the early days of the scandal. At the time the scandal broke in the public domain, the EFCC claimed that no one had brought the matter to its attention. Almost about the same time, the nation was jolted when it was revealed that a small group of senior public officials, including a permanent secretary, had been involved in a criminal conspiracy to defraud the government of N32.8 billion of police pension fund. Again, the EFCC dithered for quite a considerable time before getting involved in investigation relating to this stupendous crime. These two cases confirm the public opinion that our society is calibrated into two layers comprising of people of unequal political and financial abilities (Levi Obijiofor,2015:51)

\section{EMERGING FINANCIAL SYSTEMS}

In the Sun editorial (The Sun, August 13, 2015:17) Management of deposit transactions and the technologies employed in driving them predispose the financial institutions to abuse. In the opinion of the paper "some of them have become conduit pipes for illicit cash flows, with consequences for the economies and security of many countries". According to a report by the Washington-based Global Integrity Group Nigeria is one of the 10 largest countries for illicit financial flows in the world with about US $\$ 15.7$ billion (N3.09 trillion) illicit funds going through the banking system. A further breakdown of the report suggests that Nigeria "accounted for the lion's share of an estimated cumulative $\$ 854$ billion illicit cash flows in Africa between 1971 and 2009".

In addition to the group's revelation, and the warning by CBN, the former Director General of the Securities and Exchange Commission (now World Bank's Vice President and Treasurer), Ms Arunma Oteh, disclosed in September last year that Nigeria lost a total of $\$ 140$ billion (over N2.8 trillion) to illicit financial flows between 2002 and 2011. She told participants at the second Annual Business Lecture organized by the Convention on Business Integrity in Lagos, that over $\$ 1$ trillion had been lost through illegal activities like money laundering, tax evasion, transfer pricing and embezzlement of government funds (The Sun, August 13, 2015:17).Through compromised financial systems "drug couriers, illegal fuel exporters and oil bunkerers were said to be fleecing Nigeria of over $\$ 10$ billion (about N200 billion) annually". At the bottom of all these vice is corruption. 


\section{MODERNITY}

As the Nigerian society assumes modernity it tends to lose some of its hitherto treasured cultural practices. Some years ago people frowned at sudden wealth that appeared ill-gotten. Morality and scruples were highly esteemed. People preferred moderate incomes to corrupt lucre. With the passage of time and the entrance of drug riches and the consequent flamboyance and high-jacking of governance by corrupt permanent secretaries, drug barons, etc, beneficiaries of corruption became idolized and celebrated. They also became traditional rulers and awarded many chieftaincy titles that made them idols to the jobless and hungry youths. Thus modernity provides them with constitutional protections against undue queries into their sources of wealth. The result is a brazen scramble for pieces of the pie. Indeed some communities think lowly of their people who have access to public wealth and fail to enrich themselves and bring home some of the stolen wealth.

\section{CONCLUSIONS}

This paper set out to establish the causes, patterns and consequences of corruption in Nigeria using the historical approach. The causes of poverty in Nigeria include official impunity, indiscipline, weak justice system, lack of equitable rule enforcement, lack of political will to prosecute alleged offenders, modern day colonialism. Others are lack of honesty and integrity, abuse of cultures leading to celebration of thievery, parochialism and selfishness among those that have access to public purse. The pattern of corruption in Nigeria is top heavy. It is common among the elite who insist on placing embargoes on recruitment while they recruit their children and relations through the back doors. Consequences or costs of corruption are misallocation and misappropriation of resources, inadequate infrastructure, failures in government performance, rise of angry middle class and weak anti-corruption agencies/institutions, among others.

\section{RECOMMENDATIONS}

Any genuine attempt to reduce corruption must be determined and holistic, starting from the policy makers and legislature to avoid their decriminalizing globally known reprehensible practices. The justice system should be strengthened in terms of capacity for investigation, prosecution, litigation and diligent enforcement of court rulings. Provision of logistics in terms of donation of costly vans to the police by the state governments should be weighed against the use to which such vehicles are put, as the police often mount road blocks with them for their private financial empowerment purposes. A national rebirth or reorientation will be very useful while poverty alleviation programmes will help reduce the number of dependants of the officials, thus limiting their pressures to tamper with public funds.

\section{REFERENCES}

[1] Abak, Etim (2016) naijaparrot.com/Chinese-firm-exposes-obasanjo-el-rufai-in-841-6m-rail-project-scam

[2] Asobie, H.A.(2006) "Corruption and Poverty in Nigeria: A Dialectical Discourse”, being paper prepared for the Anti-Corruption Sensitization organized by Anti-Corruption and Transparency Unit, University of Nigeria, Nsukka, February 13,2006.

[3] Daily Sun newspaper, June 08,2015.

[4] Dewitt, Karen (2015) Former Senate Leader Skelos formally indicted on corrupton charges, WRVO Public Media wrvo.org/post/former-senate-leader-formally-indicted-corruption-charges\#stream/ 0 .

[5] Ezeani, E.O. (2010) Political Science: An Introduction, Abakaliki:WillyRose and Appleseed Publishing Company.

[6] ICPC Act (section 2) Abuja: Federal Ministry of Information.

a. informationng.com/2015/11/photos-president-buhari-talks-with-queen-elizabeth-ii.html, November 27, 2015.

[7] Karlmax2 (2014) "The buhari ptf days! The untold story" nairaland.com/2046305/buhari- ptf -daysuntold- story,December 16.

[8] Maduagwu Anthony's forthcoming book : Growing Up in Oguta : (The Economics of Rural Poverty in Nigeria), and Africa Economic Analysis 2000.

[9] Mungiu-Pippidi (2016), Alina, "Hertie School of Governance", www.hertieschool.org/executive/executive-seminars-cert accessed February.

[10] Ndibe, Okey (2015) "Where the heck is the money?", Daily Sun newspaper, November 24, back page.), sunnewsonline.com/new/ where- the- heck- is- the- money.

[11] Nkpoyen, Festus; Bassey, Glory Eteng And Uyang, Francis Abul (2014) European Journal of Business and Social Sciences, Vol. 3, No.3, pp 104-112, June. pp. $104-112$.

[12] Nwaze, Chuks (2012) "Corruption in Nigeria Exposed", Lagos: Control and Surveillance Associates Ltd.

[13] Obijiofor, Levi (2015) "EFCC,exhausted anti-corruption agency awakens”, Daily Sun, August 12,p51. 
[14] Olorunfemi, Simbo (2016) "Is the Nigerian senate so bereft of shame?", saharareporters.com/2016/04/18/ Nigerian-senate-so-bereft-of-shame- simbo-olorunfemi.

[15] Olusegun Obasanjo (2015) "African Studies in the Twenty-First Century: Past, Present and Future." Being a paper delivered at the opening ceremony of the First International Conference of the African Studies Association of Africa" held on Wednesday, October 14, hosted by the Institute of African Studies, University of Ibadan, Ibadan, Oyo state, Naija.com, December 01,2015.

[16] Oyinlola, Oluwagmamiga Ayobami,Corruption Eradication in Nigeria: An Appraisal, http://unlib.edu/LPP/ Library Philosophy and Practice 2011, Retrieved March 05, 2016.

[17] Ptf Situation Reports(Vol. 2 Dec.98) Quoted in Karlmax2 (2014) "The buhari ptf days! The untold story" nairaland.com/2046305/buhari- ptf -days- untold- story,December 16.

[18] The Independent Corrupt Practices Commission (ICPC), icpc.gov.ng/icpc-history. Retrieved March 16, 2016.

[19] The UNDP-HDI (2006) Reports.

[20] The UNDP (2010) Reports over 2000-2008.

[21] URL: http://www.ejbss.com/recent.aspx, ISSN: 2235 -767X, Retrieved March 05, 2016.

[22] www.transparency.org/what-is-corruption/?gclid=CMuF8J-B8soCFeEpOwodRecMyA, Retrieved March 10,2016.

[23] www. unodc.org/unodc/en/frontpage/nigerias-corruption-busters.html.

[24] www.un.org/.../security-highest-bidder, Retrieved February 15, 2016. 